\title{
Terrestrial and Riparian Organisms, Lakes and Streams (TROLS)
}

\author{
by Sheena A. Spencer ${ }^{1, *}$, Kevin Devito² and Ellen Macdonald ${ }^{3}$
}

\section{ABSTRACT}

The Terrestrial and Riparian Organisms, Lakes and Streams Project studied the impacts of forest harvest and riparian buffers on terrestrial and aquatic ecosystems in twelve fish-bearing lakes in the boreal mixed-wood forests of Alberta. Major results are outlined based on forest harvest and buffer effects on the landscape, water quality, and the aquatic ecosystem. Results from this project suggest that forest managers should be flexible in buffer width recommendations and should consider the entire watershed when determining the effects of disturbance due to complexities in the landscape.

\section{RÉSUMÉ}

Le Projet détude sur les organismes terrestres et riverains des lacs et des cours deau (TROLS) portait sur les effets de l'exploitation forestière et des bandes riveraines boisées sur les écosystèmes terrestres et aquatiques de douze lacs poissonneux situés dans les forêts mixtes boréales de l'Alberta. Les principaux résultats sont présentés en fonction de l'exploitation forestière et des effets tampons des bandes riveraines sur le paysage, la qualité de leau et lécosystème aquatique. Les résultats de ce projet suggèrent que les aménagistes forestiers devraient faire preuve de flexibilité dans leurs recommandations sur la largeur des bandes et qu'ils devraient tenir compte de tout le bassin versant pour déterminer les effets des perturbations en raison de la complexité du paysage.

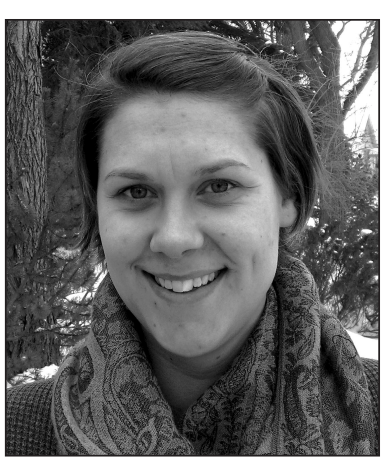

Sheena A. Spencer

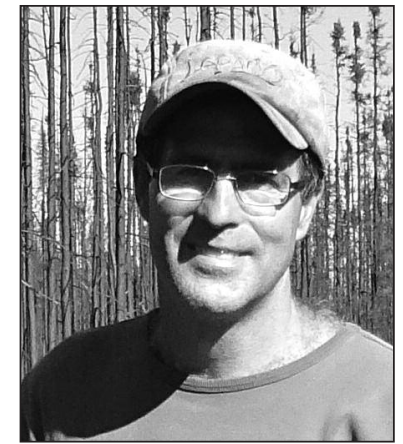

Kevin Devito

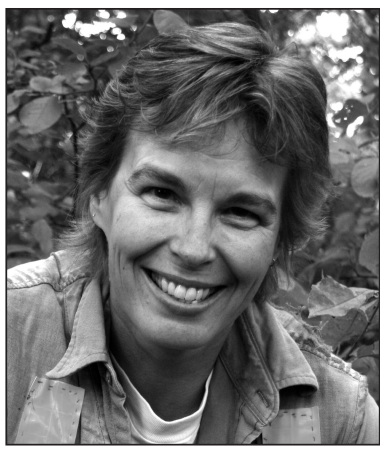

Ellen Macdonald
Twelve fish-bearing lakes surrounded by aspen-dominated boreal mixedwood forests were chosen from three regions in Alberta: Lac La Biche, South Pelican Hills and South Calling Lake (Table 2, Fig. 1). Study lakes were treated with three different riparian forest buffer widths $(20 \mathrm{~m}, 100 \mathrm{~m}$ and $200 \mathrm{~m})$ and there was one unharvested reference lake for each region (Prepas et al. 2001).

\section{Introduction}

The Terrestrial and Riparian Organisms, Lakes and Streams (TROLS) Project was a collaborative research project that ran from 1994 to 2000 and studied the impacts of forest harvest and riparian buffers on terrestrial and aquatic ecosystems (Table 1). The research was conducted in the boreal mixedwood forests of Alberta because minimal information previously existed on this forest type and Alberta's forestry guidelines of the time were adopted from standards of other provinces (Prepas 2002). The primary objectives of TROLS were to determine the effects of forest harvesting and forested buffers on "various aspects of terrestrial and aquatic ecosystems in the mixedwood forest on the Boreal Plain" (Evans et al. 2000, p 61).

\section{Results}

\section{Landscape}

- Edge effects (lakeshore or buffer edges) were observed up to $40 \mathrm{~m}$ into the forest (Harper and Macdonald 2001, 2002).

- Abundance and composition of small mammals and amphibians did not differ among buffer widths post-harvest (Hannon et al. 2002)

- Vertebrates that require a much larger habitat range (e.g., raptors, woodpeckers and mammalian carnivores) did not have adequate territory preserved in the $200 \mathrm{~m}$ buffer strips (Hannon et al. 2002).

- Forest bird diversity decreased in the $20 \mathrm{~m}$ and $100 \mathrm{~m}$ buffer strips; $200 \mathrm{~m}$ buffers were effective reserves for bird diversity (Hannon et al. 2002).

\footnotetext{
${ }^{1}$ Department of Renewable Resources, University of Alberta, Edmonton, AB; * corresponding author: saspence@ualberta.ca

${ }^{2}$ Department of Biological Sciences, University of Alberta, Edmonton, AB

${ }^{3}$ Department of Renewable Resources, University of Alberta, Edmonton, AB
} 
Table 1. Research design and variables measured for the TROLS project

\begin{tabular}{ll}
\hline Research Design \\
\hline Treatments & $\begin{array}{l}\text { Before/After; Control/Impact (BACI design) } \\
\text { Riparian buffers of varying widths from the } \\
\text { lake edge }(20,100 \text {, and } 200 \mathrm{~m}) \text { were left } \\
\text { unharvested }\end{array}$ \\
Controls & $\begin{array}{l}\text { Lakes with no harvesting or major distur- } \\
\text { bances within } 800 \mathrm{~m}\end{array}$ \\
Study duration & $\begin{array}{l}\text { 1994-2000 } \\
\text { Variables measured }\end{array}$ \\
& $\begin{array}{l}\text { Aquatic, terrestrial, and hydrologic condi- } \\
\text { tions: }\end{array}$ \\
& $\begin{array}{l}\text { Water quality, soil water and nutrients, } \\
\text { mammal tracking, snow surveys, small } \\
\text { mammals, songbirds, amphibians, and vege- } \\
\text { tation sampling }\end{array}$ \\
\hline
\end{tabular}

\section{Water quality}

- Differences in total phosphorus between pre- and postharvest were in part due to lake position and hydrologic connectivity to wetlands. Deep surficial glacial deposits and complex groundwater flow systems in the Western Boreal Forest confounded and masked the potential chemical response to disturbance in lakes (Devito et al. 2000).

- Differences in total dissolved phosphorus concentration (TDP) in mineral soil $(<1.7 \mathrm{~m})$ in cut and uncut subcatchments were not detected. Increases in ground water TDP following harvest are unlikely due to the large adsorption affinity of mineral soils and rapid regeneration of aspen. (Evans et al. 2000, Macrae et al. 2005).

- High rates of gross ammonification and nitrification were observed in soils of aspen-conifer mixed stands in harvested plots compared to unharvested plots one year following the harvest (Carmosini et al. 2002). Conversely, aspen-dominated stands showed no difference in net mineralization or nitrification (Carmosini et al. 2003), indicating large immobilization of inorganic nitrogen in both soils of harvested and un-harvested catchments (Macrae et al. 2006).

- Winter mineralization and nitrification in soils in aspen-dominated and aspen-conifer mixed stands may cause leaching of nitrogen during spring snowmelt (Carmosini et al. 2003, Macrae et al. 2006).

\section{Aquatic}

- Shallow lakes with mixed or weakly thermally stratified water columns showed the strongest increase in total phosphorus, chlorophyll $a$, cyanobacteria, and cyanotoxins concentrations in the first year after harvest (Prepas et al. 2001).

- Decreases were observed in overall zooplankton biomass and abundance post-harvest due to increase in cyanobacteria biomass in weakly or tors. non-stratified lakes and decrease in edible phytoplankton biomass in stratified lakes (Prepas et al. 2001).

- Buffer strip width did not appear to mitigate effects on inlake responses to harvest (Prepas et al. 2001).

\section{Management Implications}

- Flexibility in buffer widths is recommended to incorporate lake position, riparian zone function, and local aquatic conditions (Devito et al. 2000, Hannon et al. 2002, Creed et al. 2008).

- When determining the effects of disturbance on water quality and aquatic biota in lakes, the entire watershed should be considered due to complexities in the landscape (Devito et al. 2000) and a lack of evidence of buffer strip mitigation (Prepas et al. 2001).

\section{References}

Beaudoin, C.P., E.E. Prepas, W.M. Tonn and L.I. Wassenaar. 2001. A stable carbon and nitrogen study of lacustrine food webs in Canada's western Boreal Forest. Freshwater Biol. 46: 465-477.

Carmosini, N., K.J. Devito and E.E. Prepas. 2002. Gross nitrogen transformations in harvested and mature aspen-conifer mixed forest soils from the Boreal Plain. Soil Biol. Biochem. 24(12): 1949-1951.

Carmosini, N., K.J. Devito and E.E. Prepas. 2003. Net Nitrogen Mineralization and Nitrification in mature and logged Trembling Aspen Forest Soils on the Boreal Plain. Can. J. For. Res. 33(11): 2262-2268.

Creed, I.F., G.Z. Sass, M.B. Wolniewicz and K.J. Devito. 2008. Incorporating hydrologic dynamics into buffer strip design on the sub-humid Boreal Plain of Alberta. Forest Ecol. Manag. 256(11): 1984-1994. doi: 10.1016/j.foreco.2008.07.021

Devito, K.J., I.F. Creed, R.L. Rothwell and E.E. Prepas. 2000. Landscape controls on phosphorus loading to boreal lakes: Implications for the potential impacts of forest harvesting. Can. J. Fish. Aquat. Sci. 57: 1977-1984.

Evans, J.E., E.E. Prepas, K. Devito and B.G. Kotak. 2000. Phosphorus dynamics in shallow subsurface waters in an uncut and cut subcatchment of a lake on the Boreal Plain. Can. J. Fish. Aquat. Sci. 57(Suppl. 2): 60-72.

Table 2. Summary of the TROLS project watershed and climatic descrip-

\begin{tabular}{ll}
\hline & Watershed Location Data \\
\hline Location (descriptive) & $\begin{array}{l}\text { Southern portion of Alberta's Boreal } \\
\text { Mixedwood Ecoregion }\end{array}$ \\
Location (geographic) & $\begin{array}{l}\text { Lac La Biche: } 55^{\circ} 08^{\prime} \mathrm{N} 111^{\circ} 45^{\prime} \mathrm{W} \\
\text { South Calling Lake: } 55^{\circ} 07^{\prime} \mathrm{N} 113^{\circ} 43^{\prime} \mathrm{W} \\
\text { South Pelican Hills: } 55^{\circ} 23^{\prime} \mathrm{N} 113^{\circ} 38^{\prime} \mathrm{W}\end{array}$ \\
$\begin{array}{ll}\text { Biogeoclimatic zone } \\
\text { Drainage basin area (range) }\end{array}$ & $\begin{array}{l}\text { Headwater lakes: } 455-1053 \text { ha; non- } \\
\text { headwater lake (SCL200): } 5669 \text { ha }\end{array}$ \\
Precipitation (mean annual)* & $<485$ mm \\
Temperature (mean monthly) & July: $18^{\circ} \mathrm{C}$ \\
& January: $-17^{\circ} \mathrm{C}$ \\
\hline
\end{tabular}

${ }^{*}$ Beaudoin et al. 2001

${ }^{*}$ Evans et al. 2000 


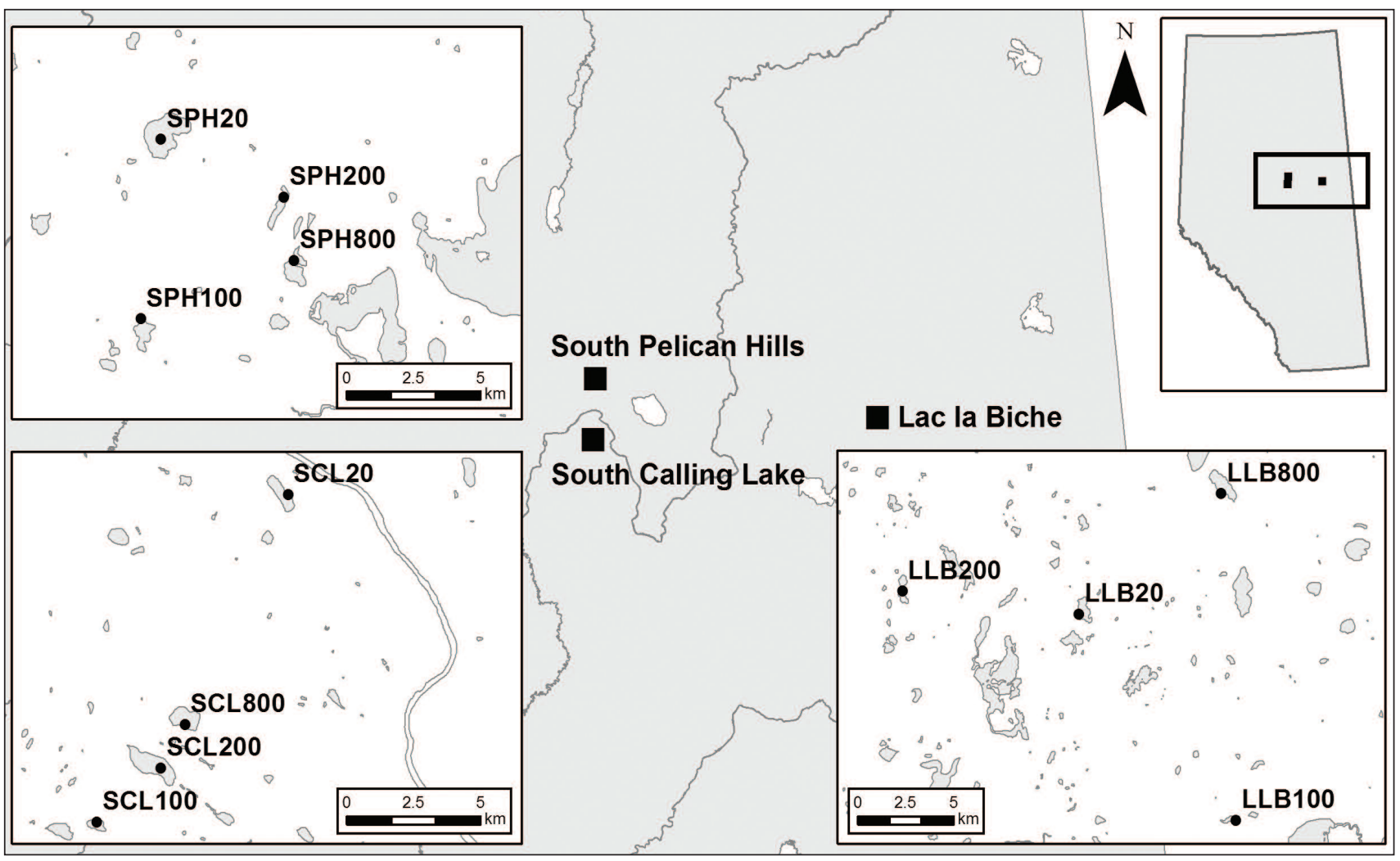

Fig. 1. Location of the 12 TROLS study lakes in the South Pelican Hills (SPH), South Calling Lake (SCL), and Lac La Biche (LLB) regions of north central Alberta. The numbers 20 to 800 indicate the width of buffer treatment following harvesting in the lakes, winter 1997.

Hannon, S.J., C.A. Paszkowski, S. Boutin, J. DeGroot, S.E. Macdonald, M. Wheatley and B.R. Eaton. 2002. Abundance and species composition of amphibians, small mammals, and songbirds in riparian forest buffer strips of varying widths in the boreal mixedwood of Alberta. Can. J. For. Res. 32: 1784-1800. doi: 10.1139/X02092.

Harper, K.A. and S.E. Macdonald. 2001. Structure and composition of riparian boreal forest: New methods for analyzing edge influence. Ecology 82: 649-659.

Harper, K.A. and S.E. Macdonald. 2002. Structure and composition of edges next to regenerating clear-cuts in the mixed-wood boreal forest. J. Veg. Sci. 13: 535-546.

Macrae, M.L., I.F. Creed, E. Macdonald and K.J. Devito. 2006. Relation of soil-, surface-, and ground-water distributions of inor- ganic nitrogen with topographic position in harvested and unharvested portions of an aspen-dominated catchment in the Boreal Plain. Can. J. For. Res. 36: 2090-2103. doi: 10.1139/x06-101.

Macrae, M.L., T. Redding, I.F. Creed, W. Bell and K.J. Devito. 2005. Soil, surface water and groundwater phosphorus relationships in a partially harvested Boreal Plain aspen catchment. For. Ecol. Manage. 206: 315-329.

Prepas, E.E. 2002. Terrestrial and Riparian Organisms, Lakes and Streams. Collaborative research project. Overview for partners, September 2002. $22 \mathrm{p}$.

Prepas, E.E., B. Pinel-Alloul, D. Planas, G. Méthot, S. Paquet and S. Reedyk. 2001. Forest harvest impacts on water quality and aquatic biota on the Boreal Plain: Introduction to the TROLS lake program. Can. J. Fish. Aquat. Sci. 58: 421-436. doi: 10.1139/cjfas-58-2-421. 